\title{
Pengaruh Metode Penyayatan Laju Tinggi dan Sudut Buang Pahat Terhadap Kekasaran Permukaan Hasil Bubut Rata Menggunakan Pahat HSS Pada Bahan Bronze
}

\author{
Muhammad Farid Irvan 1), Abdul Qolik ${ }^{2)}$, Basuki ${ }^{3)}$ \\ 1,2,3 Program Studi S1 Pendidikan Teknik Mesin Jurusan Teknik Mesin \\ ${ }^{1,2,3}$ Fakultas Teknik Universitas Negeri Malang \\ 1,2,3 Jalan Semarang No. 5, Malang 65145 \\ Email: Mfaridirvan@gmail.com
}

\begin{abstract}
Abstrak: Tujuan penelitian ini adalah untuk mengetahui pengaruhan dari kecepatan putaran spindle, gerak makan (feed rate), dan sudut buang pahat terhadap kekasaran permukaan pada proses pembubutan bahan bronze. Penelitian ini menggunakan metode eksperimental dengan desain Pre Eksperimental. Teknik analisis data dalam penelitian ini adalah two way anova. Dengan variabel penelitian kecepatan putaran spindle (X1), kedalaman pemotongan (X2), dan gerak makan (feed rate) (X3) berpengaruh terhadap kekasaran permukaan (Y). Hasil menunjukkan kecepatan spindle pada $1250 \mathrm{Rpm}$, pada variasi gerak makan $0.050 \mathrm{~mm} / \mathrm{rev}$, dan sudut buang pahat pada $3^{\circ}$ memiliki kekesaran permukaan yang relatih rendah.
\end{abstract}

Kata kunci: kecepatan putaran spindle, gerak makan, sudut buang pahat, kekasaran permukaan

Pengerjaan dengan mesin sudah menjadi kebutuhan pada industri manufaktur. Mesin memiliki peran yang penting dalam membatu manusia dalam proses produksi, pekerjaan menjadi lebih baik dalam segi hasilnya dan kecepatannya sesuai yang dikehendaki. Proses pembubutan merupakan salah satu proses yang paling sering dijumpai dalam pemesinan. Pada proses bubut bahan dicekam pada spindel putar, prosesnya juga memerlukan pahat sebagai penyayat bahan. Pergerakan penyayatan pahat yang menentukan bentuk dari produknya. Pahat digunakan mengurangi dimensi dari benda kerja. Pahat bubut berperan sangat penting dalam proses pemesinan terutama dalam proses bubut, karena itu dimensi dan geometri dari pahat bubut harus diperhatikan agar benda kerja yang dihasilkan sesuai yang dinginkan.

Terdapat beberapa faktor dalam proses pembubutan yang harus direncanakan sebelum pelaksanaannya. Di antara faktor - faktor tersebut salah satunya adalah parameter pembubutan. Parameter - parameter yang dimaksud adalah kecepatan putar spindel, sudut buang pahat dan gerak makan (feeding rate). Melalui pengunaan parameter yang direncanakan dapat diketahui kekasaran benda bubut. Pada penelitian ini parameter yang hendak digunakan sebagai variabel penelitian adalah kecepatan putaran spindle, dan sudut buang pahat untuk mengetahui tingkat kekasaran bahan, bahan yang digunakan pada proses pembubutan material bronze dengan panjang bidang pembubutan yang telah ditentukan.

Perunggu ialah paduan tuang yang tahan terhadap korosi. Ketahanan korosinya yang bagus menyababkan perunggu aluminium disukai untuk aplikasi kelautan, roda gigi cacing, katup dan alat-alat pembentuk yang tidak mencetuskan bunga api (A. Schey John, 2000). Dengan segala manfaat perunggu peniliti mencoba untuk memakai perunggu sebagai bahan penilitian. Karakteristik kekasaran permukaan suatu benda kerja dapat dihasilkan dari kondisi pemotongan dan geometri dari pahat potong. Untuk mendapatkan nilai kekasaran permukaan dari poros yang halus pada proses bubut dapat dilakukan dengan pemilihan mata pahat, penentuan feeding dan kedalaman potong yang sesuai dengan kebutuhan. Ketajaman dan kekuatan dari mata pahat sangat berpengaruh terhadap produk yang dihasilkan. Dalam penelitian ini difokuskan pada penggunaan pahat HSS dan material bronze untuk mengetahui pengaruh pahat HSS dengan variasi sudut buang pahat dan benda kerja terhadap kekasaran permukaan yang dihasilkan.

\section{METODE PENELITIAN}

\section{Rancangan Penelitian}

Pada penelitian ini menggunakan penelitian deskriptif eksperimental. Dengan variabel penelitian kecepatan putaran spindle (X1), kedalaman pemotongan $\left(\mathrm{X}_{2}\right)$, dan gerak makan (feed rate) $\left(\mathrm{X}_{3}\right)$ berpengaruh terhadap kekasaran permukaan $(\mathrm{Y})$.

\section{Bahan}

Bahan yang digunakan bahan bronze (perunggu) dengan diameter sebesar $25.5 \mathrm{~cm}$, panjang bahan yang digunakan 100 $\mathrm{mm}, 65 \mathrm{~mm}$ untuk proses pembubutan. 


\section{Prosedur Pembubutan}

Proses pembubutan tidak menggunakan pendingin dan menggunakan metode penyayatan memanjang. Pahat yang digunakan adalah pahat HSS (High Speed Steel), setiap satu mata pahat digunakan untuk satu benda kerja. Mesin bubut yang digunakan adalah mesin bubut konvensional dengan merk Ann Yang, model DY-410G.

\section{Uji Kekasaran Permukaan}

Pengujian kekasaran permukaan dilakukan dijurusan teknik mesin Universitas Negeri Malang. Pengambilan data setiap benda kerja diambil 2 kali pengujian. Untuk mengukur kekasaran permukaan menggunakan Surface Test Merk Mitutoyo Model Portable SURF-TEST SJ-301 Series.

\section{Anailisis Data}

Dalam penelitian ini analisis data yang digunakan adalah uji hipotesis pada statistik inferensial parametric (General Linier Model UNIVARIATE) atau two way anova. Sebelum melakukan uji persyaratan analisis statistik parametrik pada data yang terkumpul. Pengujian ini terlebih dahulu melakukan pengujian normalitas dan pengujian homogenitas.

\section{HASIL DAN PEMBAHASAN}

Hasil pengukuran kekasaran permukaan yang diperoleh dapat dilihat pada table

Tabel 1. Hasil pengukuran kekasaran permukaan

\begin{tabular}{|c|c|c|c|c|c|}
\hline \multicolumn{2}{|c|}{ Variabel } & \multirow{2}{*}{\multicolumn{3}{|c|}{$\begin{array}{c}\text { Kekasaran permukan }(\mu \mathrm{m}) \\
\text { Gerak Makan (mm/rev) }\end{array}$}} & \multirow{3}{*}{$\begin{array}{c}\text { Rata-rata Kekasaran } \\
\text { Berdasarkan Kecepatan } \\
\text { Spindle dan Sudut } \\
\text { Buang Pahat HSS }(\mu \mathrm{m})\end{array}$} \\
\hline \multirow{2}{*}{$\begin{array}{c}\text { Kecepatan Putaran } \\
\text { Spindle (rpm) }\end{array}$} & \multirow{2}{*}{$\begin{array}{l}\text { Sudut Buang } \\
\text { Pahat HSS }\end{array}$} & & & & \\
\hline & & 0,050 & 0,100 & 0,200 & \\
\hline \multirow[t]{3}{*}{630} & $3^{\circ}$ & 1,15 & 1,82 & 3,39 & 2,12 \\
\hline & $10^{\circ}$ & 1,04 & 2,79 & 3,58 & 2,47 \\
\hline & $20^{\circ}$ & 3,01 & 3,42 & 7,28 & 4,57 \\
\hline \multirow[t]{3}{*}{920} & $3^{\circ}$ & 0,68 & 1,74 & 2,31 & 1,57 \\
\hline & $10^{\circ}$ & 1,03 & 2,52 & 2,85 & 2,13 \\
\hline & $20^{\circ}$ & 1,32 & 2,71 & 6,69 & 3,57 \\
\hline \multirow[t]{3}{*}{1250} & $3^{\circ}$ & 0,59 & 1,23 & 1,82 & 1,21 \\
\hline & $10^{\circ}$ & 0,69 & 2,34 & 2,72 & 1,91 \\
\hline & $20^{\circ}$ & 0,92 & 2 & 6,33 & 3,08 \\
\hline \multirow{4}{*}{$\begin{array}{c}\text { Rata-rata Kekasaran } \\
\text { Berdasarkan Kecepatan } \\
\text { Spindle dan Gerak } \\
\text { Makan }(\mu \mathrm{m})\end{array}$} & Putaran spindel & & & & \\
\hline & 630 & 1,73 & 2,67 & 4,75 & \\
\hline & 920 & 1,01 & 2,32 & 3,95 & \\
\hline & 1250 & 0,73 & 1,85 & 3,62 & \\
\hline
\end{tabular}

Berdasarkan data pada tabel diatas, dapat dikatakan bahwa hasil spesimen (benda kerja) setelah dilakukan pembubutan laju tinggi dan variasi sudut buang pahat bubut mengasilkan kekasaran permukaan spesimen yang berbeda. Didapatkan nilai ratarata kekasaran permukaan berdasarkan kecepatan putaran spindle dan gerak makan yang paling rendah terdapat pada putaran spindle $1250 \mathrm{Rpm}$ dan gerak makan pada $0.050 \mathrm{~mm} / \mathrm{rev}(0,73 \mu \mathrm{m})$, sedangkan untuk rata-rata paling rendah berdasarkan kecepatan putaran spindle dan sudut buang pahat HSS paling rendah pada putaran spindle 1250 Rpm dan sudut buang $3^{\circ}(1,21 \mu \mathrm{m})$.

Uji hipotesis dilakukan dengan two way anova dimana mampu menguji pengaruh suatu variabel terhadap rata-rata variabel dependen pada berbagai kelompok, maka uji prasyaratnya adalah uji normalitas dan uji homogenitas variance. Hasil uji normalitas dengan metode Kolmogrov Smirnov, nilai signifikansi sebesar 0,047. Oleh karena signifikansinya kurang dari 0,05 maka dapat disimpulkan bahwa distribusi data kekasaran permukaan adalah normal. Hasil uji homogenitas diperoleh signifikansi 
0,001, kurang dari 0,05. Dengan demikian data penelitian diatas homogen antar perlakuan. Maka dapat dikatakan bahwa uji homogenitas varians terpenuhi. Dari uji normalitas dan homogenitas varian yang sudah dilakukan diperoleh sebaran data normal dan homogenitas varian terpenuhi maka dapat dilakukan uji hipotesis.

Uji hipotesis didapatkan hasil bahwa kecepatan putaran terdapat nilai signifikansi 0.005 karena taraf nilai signifikansi < 0.05, maka dapat diartikan bahwa hipotesis nol ditolak. Dengan ditolak hipotesis nol dapat diartikan bahwa ada pengaruh langsung antara variasi kecepatan putaran terhadap kekasaran permukaan hasil pembubutan pada material bronze. Pada barisan gerak makan terdapat nilai signifikansi 0.000 karena taraf nilai signifikansi $<0.05$, maka dapat diartikan bahwa hipotesis nol ditolak. Dengan ditolaknya hipotesis nol dapat diartikan bahwa adanya pengaruh langsung antara variasi gerak makan terhadap kekasaran permukaan hasil pembubutan pada material bronze. Pada barisan sudut buang pahat terdapat nilai signifikansi 0.016 karena taraf nilai signifikansi $<0.05$, maka dapat diartikan bahwa hipotesis nol ditolak. Dengan ditolaknya hipotesis nol dapat diartikan bahwa ada pengaruh langsung antara variasi sudut buang pahat terhadap kekasaran permukaan hasil pembubutan pada material bronze. Diketahui bahwa gerak makan mempunyai nilai signifikan kurng dari 0.05 yang berarti Ho di tolak dan dapat dikatakan bahwa ada pengaruh tingkat kekasaran permukaan proses pembubutan material bronze dengan variasi kecepatan putaran spindle, gerak makan, dan sudut buang pahat HSS.

\section{Pengaruh Kecepatan Putaran Spindle terhadap Kekasaran Permukaan Proses Pembubutan Bahan Bronze}

Dalam penelitian ini kecepa- tan putaran spindle juga berpengaruh secara signifikan terhadap kekasaran permukaan dari proses pembubutan bahan bronze. Dapat diketahui variasi kecepatan putaran spindle yang memiliki nilai rata-rata kekasaran permukaan paling rendah pada putaran $1250 \mathrm{rpm}$. Dari penelitian yang dilakukan peneliti dapat diartikan bahwa putaran spindel yang cenderung kecil dapat menghasilkan kekasaran permukaan yang relatif kasar, sebaliknya semakin tinggi kecepatan putaran spindel akan menghasilkan permukaan material yang relatif halus. Penelitian ini selaras dengan yang dilakukan Raul (2014) yang menyatakan bahwa semakin tinggi kecepatan potong yang digunakan maka hasil kualitas semakin halus dan baik. Begitu pula penelitian yang dilakukan oleh Figa (2015) menyatakan bahwa kecepatan putaran tinggi menghasilkan permukaan yang baik dan kecepatan putaran sangat berpengaruh terhadap kekasaran. Begitu juga yang dinyatakan oleh Pebri dan Arief (2014) semakin tinggi kecepatan putar spindle, maka semakin rendah tingkat kekasaran permukaan benda kerja.

\section{Pengaruh Gerak makan terhadap Kekasaran Permukaan Proses Pembubutan Bahan Bronze}

Dalam penelitian ini gerak makan juga berpengaruh secara signifikan terhadap kekasaran permukaan dari proses pembubutan bahan bronze. Dapat diketahui bahwa untuk variasi gerak makan yang memiliki nilai rata-rata kekasaran permukaan paling rendah terdapat pada gerak makan $0,050 \mathrm{~mm} / \mathrm{rev}$. Dari hasil penelitian dapat diartikan bahwa semakin besar nilai gerak makan akan mendapat nilai kekasaran permukaan yang relatif kasar, dan sebalik semakin kecil nilai gerak makan akan menghasilkan nilai kekasaran permukaan yang relatif halus. Munadi (1988) menyatakan bahwa tingkat kekasaran yang tinggi bisa terjadi karena adanya pengaruh dari proses pemesinan seperti dari proporsi dari putaran spindle, gerak makan dan pisau potong dalam proses pembuatannya. Hasil analisis ini juga selaras dengan penelitian yang dilakukan oleh Febi (2015) bahwa semakin kecil gerak makan (feeding) yang digunakan maka tingkat kekasaran permukaannya semakin kecil, begitu pula sebaliknya. Menurut Zubaidi 2012 "Harga feeding (gerak makan) berpengaruh pada tingkat kekasaran permukaan, semakin besar harga feeding semakin besar tingkat kekasarannya". Begitu juga dikemukaan dalam penelitian Figa (2015) yang menyebutkan bahwa gerak makan yang semakin kecil menghasilkan kualitas permukaan yang baik

\section{Pengaruh Sudut Buang Pahat terhadap Kekasaran Permukaan Proses Pembubutan Bahan Bronze}

Dalam penelitian ini variasi sudut buang pahat HSS yang nilai rata-rata kekasaran permukaannya paling halus yaitu pada sudut $3^{\circ}$. Pada sudut buang pahat $3^{\circ}$ diperoleh tingkat kekasaran permukaan yang halus jika dibandingkan dengan yang lain, yaitu dengan nilai $R_{a} 0.59 \mu \mathrm{m}$. Pada penelitian ini variasi sudut buang pahat HSS dapat diartikan semakin kecil sudut buang pahat akan diperoleh kekesaran permukaan yang relatif halus, dan sebaliknya nilai sudut buang pahat yang besar akan diperoleh nilai kekasarn permukaan yang relatif kasar. Wirawan. S (2008) menyatakan bahwa kekerasan benda kerja mempengaruhi sudut buang pahat, semakin keras benda kerja semakin kecil sudut buang pahatnya bahkan ada pada sudut $0^{\circ}$ atau bahkan negatif.

Hal itu selaras dengan penelitian yang dilakukan oleh Ardiyan (2012) menyatakan bahwa variasi sudut potong berpengaruh terhadap kekasaran permukaan, dimana semakin besar sudut potong yang digunakan maka tingkat kekasaran permukaan semakin rendah. Hal serupa juga dikemukakan oleh Rochim (1993), sudut potong utama (Kr) mempunyai peran antara lain menentukan lebar dan tebal geram sebelum terpotong (b dan h). Menentukan panjang mata potong yang aktif atau panjang kontak antara geram dengan bidang pahat, dan menentukan besarnya gaya.

\section{Pengaruh Kecepatan Putaran Spindle, Gerak Makan, dan Sudut Buang Pahat Terhadap Kekasaran Permukaan Proses Pembubutan Bahan Bronze.}

Dalam penelitian ini dapat diketahui bahwa kecepatan putaran spindel, gerak makan, dan sudut buang pahat memiliki pengaruh terhadap kualitas yang diperoleh dari hasil penelitian kekasaran permukaan yang berbeda. Dari hasil pengujian 
kekasaran permukaan dapat diketahui untuk variasi kecepatan putaran spindel, gerak makan, dan sudut buang pahat memiliki pengaruh terhadap adalah pada kecepatan putaran spindel $1250 \mathrm{rpm}$, gerak makan $0,050 \mathrm{~mm} / \mathrm{rev}$, dan sudut buang pahat $3^{\circ}$. Pada kecepatan putaran spindel $1250 \mathrm{rpm}$, gerak makan $0,050 \mathrm{~mm} / \mathrm{rev}$, dan sudut buang pahat $3^{\circ}$ nilai kekasaran permukaannya adalah $0,59 \mu \mathrm{m}$.

Pada penelitian dengan variasi kecepatan putaran spindel, gerak makan, dan sudut buang pahat memeliki pengaruh terhadap kekasaran permukaan bahan bronze pada proses bubut konvensional. Kecepatan putaran spindle semakin tinggi maka akan menghasilkan kekasaran permukaan yang halus, begitu sebaliknya putaran rendah akan menghasilkan permukaan yang kasar. Pada variasi gerak makan semakin rendah akan menghasilkan kekasaran permukaan yang halus, begitu sebaliknya gerak makan yang tinggi akan menghasilkan permukaan yang kasar. Sudut buang pahat semakin kecil akan menghasilkan kekasaran permukaan yang halus, begitu sebaliknya sudut buang pahat yang besar akan menghasilkan permukaan yang kasar.

\section{Kesimpulan}

\section{SIMPULAN DAN SARAN}

Berdasarkan hasil pengujian dan analisis data dapat disimpulkan bahwa terdapat pengaruh pada variasi kecepatan putaran spindle secara signifikan terhadap kekasaran per- mukaan pada proses pembubutan bahan bronze. Bahwa semakin tinggi kecepatan putaran spindle maka hasil kekasaran permukaannya semakin halus. Pada variasi gerak makan secara signifikan terhadap tingkat kekasaran permukaan pada proses pembubutan bahan bronze. Semakin tinggi gerak makan maka hasil kekasaran permukaannya akan semakin kasar. Terdapat pengaruh pada variasi sudut buang pahat HSS secara signifikan terhadap tingkat kekasaran permukaan pada proses pembubutan bahan bronze. Semakin besar sudut buang pahat maka tingkat hasil kekasaran permukaannya akan semakin kasar. Variasi parameter pembubutan yang terbaik pada kecepatan putaran spindel $1250 \mathrm{rpm}$, gerak makan $0,050 \mathrm{~mm} / \mathrm{rev}$, dan sudut buang pahat $3^{\circ}$. Pada kecepatan putaran spindel $1250 \mathrm{rpm}$, gerak makan $0,050 \mathrm{~mm} / \mathrm{rev}$, dan sudut buang pahat $3^{\circ}$ nilai kekasaran permukaannya adalah $0,59 \mu \mathrm{m}$. Nilai kekasaran ini termasuk kelas N6.

\section{DAFTAR RUJUKAN}

Ayodeji, O., dkk. 2015. Effect of Cutting Speed and Feed Rate on Tool Wear Rate and Surface Roughness in Lathe Turning Process, (online), 173 - 175, (http://www.ijettjournal.org/), diakses 18 April 2017.

Kalpakjian, S., dan Scmid R Steven. 2002. Manufacturing Engineering and Technologi Fourth edition. London: Prentice Hall.

Lie, Raul Antonius. 2014. Pengaruh Variasi Kecepatan Potong Dan Kedalaman Potong Pada Mesin Bubut Terhadap Tingkat Kekasaran Permukaan Benda Kerja ST 41. Skripsi tidak di terbitkan. Malang: Universitas Negeri Malang.

Munadi, Sudji. 1988. Dasar-dasar Metrologi. Jakarta: Proyek Pengembangan Lembaga Pendidikan Tenaga Pendidikan

Rahmadianto, Febi. 2015. Pengaruh Variasi Cutting Fluid dan Variasi Feeding pada Proses Pemotongan Orthogonal Poros Baja Terhadap Kekasaran Permukaan. Widya Teknika

Rochim, T. 1993. Teori \& Teknologi Proses Permesinan Laboratorium Produksi. Dan Metalurgi Industry. Bandung: Jurusan Teknik Mesin ITB.

Schey, J. A. 2000. Introduction to Manufacturing Processes. McGraw-Hill.

Sumbodo, Wirawan. 2008. Teknik Produksi Mesin Industri Jilid 2. Jakarta : Direktorat Jenderal Manajemen Pendidikan Dasar dan Menengah Departemen Pendidikan Nasional.

Susarno, Ardiyan. 2012. Studi Pengaruh Sudut Potong Pahat Hss Pada Proses Bubut Dengan Tipe Pemotongan Orthogonal Terhadap Kekasaran Permukaan. Skripsi ini tidak diterbitkan. Surakarta: Universitas Muhammadiyah Surakarta

Ubaid, Figa Rosyadi. 2015. Pengaruh Kecepatan Putaran Spindle Dan Kecepatan Pemakanan (Feeding) Pada Proses Turning Cnc Terhadap Kekasaran Permukaan Baja SS 41. Skripsi tidak di terbitkan. Malang: Universitas Negeri Malang.

Zubaidi, A, Darmanto S.A. 2012. Analisis Pengaruh Kecepatan dan Kecepatan Pemakanan Terhadap Kekasaran Permukaan Material FCD 40P pada Mesin Bubut CNC. Skripsi ini tidak diterbitkan. Semarang: Universitas Wahid Hasyim 